\title{
Nuclear energy status in Russia: Historical and contemporary perspectives
}

\author{
YelizavetaMikhailovnaSharonova \\ (Political Science Department, Delhi University, India)
}

\begin{abstract}
Russia Is Blessed With Vast Reserves Of Hydrocarbons. However, Russia Has Continuously Accorded Nuclear Energy A Place Of Importance In Its Development Policies. The Study Gives An Account Of The Historical, Socio-Political And Economic Landscape Of Russia That Shapes Its Nuclear Energy Status. The Study Shows That Despite The Fact That The Country Is Rich Of Hydrocarbon Recourse, Historical And Economic Factors Determined High Status Of Nuclear Energy In Russia.

Keywords-Russia, nuclear energy/power, history, energy policies, economic development
\end{abstract}

\section{INTRODUCTION}

The Russian Federation has vast reserves of natural gas, coal, and oil (Mitrova 2014). However, not only hydrocarbons, but also nuclear energy has played, and continues to play, a strategically important role in the country policies. While international concerns toward Russian hydrocarbon energy resources have considerable resonance in social and political studies, less attention has been given to examining the status of nuclear energy in Russia. The main objective of this study is to give an account on status nuclear energy had in the history of the Soviet Union and how it is determined in the contemporary Russia.

The present study starts from presenting historical facts that framed the attitude toward nuclear energy in Russia and thendiscusses economic determinants of the status nuclear energy has in this country. The study also provides a note regarding the impact of the Chernobyl and Fukushima nuclear accidents on nuclear energy sector and the public's attitude to nuclear energy development in Russia.

\section{DEVELOPMENT OF NUCLEAR TECHNOLOGIES IN RUSSIA}

Nuclear energy status is deeply rooted in the country's history. Level of education and trust in science are among the determinants of public attitude to risks technologies such as nuclear energy(Slovic and Peters 2006). The Russian nuclear energy status cannot be well represented without a brief description of the postRevolution period when the Russian energy sector was re-established and mass education was developed. The Russian revolution, also known as the Great October revolution, liquidated foreign monopolies of national resources through its nationalization, raised level of mass education, and modernized infrastructure and industry; these achievements transformed Russia from agrarian to industrial country which improved the economy and as a result the loans and debts of imperial Russia were paid off. Consequently, the United Soviet Socialistic Republic (USSR) in 26 June 1954 became the first country in the world to adapt the energy of atom to produce electricity for civil use (Freeman 2007).

\subsection{Catch Up And Outdo!}

The 1917 Russian revolution is a key moment in Russian political history and its energy development. During the post-Revolution period energy sector was modernized and mass education was significantly raised (Yerofeev 2003). Before the Russian revolution, development of energy industry was slow as foreign investors, such as English, French, German, American, and Belgian, had control of Russian energy resources and economy (Lapayeva and Lapayev 2004). About 56 per cent of coal mining and 90 per cent of the electro/technical enterprises were concentrated in foreign hands. Moreover, these foreign capitalists shaped the external politics of the country, particularly Russian participation in World War I (Maevskiy 1957).

Using cheap natural and labour resources, foreign companies made huge profits while workers' incomes and the quality of life in Russia were much lower than in Europe and the United States of America (USA). In 1900, the average annual income in the Russian Empire was around 63 rubles, while it was around 346 rubles in the USA (Yerofeev 2003). Before the Great October revolution, over 76 per cent of Russian population was occupied in the agricultural sector and only 10 per cent in the industrial sector (Maevskiy 1957). According to a poll that was conducted in 1897, only 21.1 per cent (29.3 per cent for men, 13.1 per cent for women) of the population in the Russian Empire was literate (Yerofeev 2003). Perhaps the rise of energy sector would not have happened without the occurrence of the Great October revolution and its outcomes such as nationalization of natural resources, dynamic modernization of industry, and rise of educational level among the 
people. The Great October revolution liquidated foreign monopolization of resources, loans and debts of imperial Russia (Maevskiy 1957). The revolution transformed Russia from an agrarian to an industrial country. It urbanized Russia and created an entirely educated population (Yerofeev 2003).

Due to the great interest of western countries in Russian natural and labour resources, the probability of war was high. This pressure determined the USSR competition ideology 'Catch up and outdo!' The USSR had only two choices; either to lose its independence or to build up a strong country within a short period of time. To develop a strong country, the USSR government, first of all, paid strong attention to electrification of the country and development of human resource (Andrews 2013).

One of the modernisation steps was the improvement of education level among proletarian. In the 1920s, Mass Literacy Campaign, known as LikBez, was launched (Andrews 2013). Aphorism and political slogans depicted the progress of mass education during the USSR time. One of the political slogans of the postrevolution time was 'Eradicate illiteracy!'. Another slogan was Lenin's slogan 'We have to study, study and study even more!'. Stalin's slogan 'Specialist resources determine everything!' reflected the need of high-level specialists and scientists, as qualified specialists were seen as those on whom the success of USSR would depend (Levchuk 2011).

The other important point in the country's development was its electrification. The electrification plan and its success were reflected in several aphorisms such as 'There was an oil lamp or a candle and now Ilyich's lamp' and the Soviet Union Premier Vladimir Ilyich Lenin's popular aphorism 'Communism equals Soviet power plus electrification of the whole country'. At that time, electrification of the country depended on the modernisation and development of coal, oil and peat mining. Coal mining from 1913 to 1920 grew by 23.4 per cent, for the same period, oil production grew by 41.4 per cent, and in 1932 the USSR reached the level of 22.3 million tons of oil mining and became the second country in oil production in the world (Lapayeva and Lapayev 2004). The growth of electricity generation is given in the Table 1.

Table 1:Electricity generation in the USSR from 1913 to 1937

\begin{tabular}{|l|l|l|l|}
\hline Year & Electricity generation & Year & Electricity generatin \\
\hline 1913 & 1,945 million $\mathrm{kWh}$ & 1932 & 13,5 million $\mathrm{kWh}$ \\
\hline 1928 & 5,007 million $\mathrm{kWh}$ & 1937 & 36.4 million $\mathrm{kWh}$ \\
\hline
\end{tabular}

Source: Lapayeva and Lapayev 2004

Renewable energy, such as hydro energy, was also developed during the Soviet era. Development of hydropower in the USSR started as early as 1922. During the USSR time, the Sayano-Shushenskaya Dam, which is the sixth largest hydroelectric plant in the world, was built. Volga Hydroelectric station, the largest hydroelectric station in Europe, and many other hydroelectric stations were built. In 1960s, the USSR ranked second in the world in terms of total installed hydropower capacity, and third in terms of hydro-electric power production (RussHydro.ru 2011).

\subsection{Nuclear Technologies}

In the Soviet Union's time, nuclear energy was something more than just a source of energy; it was a sign of the Soviet Union's success. Utilization of nuclear fuels for energy production goes back to early 1954 when Russia was a part of the Soviet Union. Since then, the interest in nuclear energy continued to rise and the share of nuclear energy to the total energy production continued to grow accordingly. In post-revolution (19171922) and Stalin's periods (1922-1953), the fundamental base of Russia's industrial sector was created, while in the so called Khrushchev era (1953-1964), successes in nuclear power and space technologies were achieved (Andrews 2013).

In 1945 the USSR won the World War II. Although Axis countries lost the war, the USSR was exhausted and was faced with a new type of weapon i.e. nuclear bomb that was possessed by only one country - the USA. Even the USSR was exhausted after World War II, it became the second country in the world to gain that super weapon technology. The USSR/Russia is one of the five recognised Nuclear-Weapon States. In 1985, the Soviet Union signed the treaty on the Non-Proliferation of Nuclear Weapons (NPT). The NPT is also known as a three-pillar system as it has three main concepts i.e. non-proliferation, disarmament, and peaceful uses of nuclear technologies (Singh 2013). The main peaceful applications of nuclear technologies in Russia are: energy production; desalination of water, production of hot water for regular winter heating systems, medicine, and discovery of the cosmos.

\subsection{Peaceful uses of nuclear technologies}

The USSR is a pioneer in the peaceful use of atomic energy. It launched the first reactor in the world in the year 1954 (Freeman 2007). It was launched by the Russian State Scientific Center-Institute of Physics and Power Engineering (IPPE) and called 'Атом Мирный' or 'Peaceful Atom' and abbreviated as 'AM-1'. The 
AM-1 provided electricity, heated water for the regular heating system of Obninsk city and served also as a research reactor (Pomper 2009). The AM-1 is a light-water-cooled-graphite-moderated-channel type reactor,in Russian it is ReaktorBolshoyMoshchnostiKanalniy (RBMK). This type of reactor was used in the Chernobyl Nuclear Power Plant (NPP) that blew up in 1986 due to human error (Semenov 1982). However, the RBMK reactor AM-1 had been working for 50 years when it was stopped (Zhmurikov et al. 2010).

The Soviet Union was not only a pioneer in the construction of NPP, but also in nuclear vessels as well (Pomper 2009). In 1959, the world's first nuclear-powered ice-breaker 'Lenin' was constructed. It was followed by the ice-breaker 'Arctic' in 1974, and the ice-breaker 'Siberia' in 1977 and others later on. Nuclear energy development in the USSR helped Russia to hold leading position in surveying the Arctic polar region (Semenov 1982). Russian dominance in Arctic survey is not only of scientific value. Huge reserves of oil were believed to be present in the Russian part of the Arctic (Solanko 2013).

The first Fast Breeder Reactor (FBR) in the world was developed in 1955 in the Russian city Obninsk (Semenov 1982). Since then, Russia has maintained a leading position with its fast breeder/neutron reactor technology (WNA 2015). The first FBR was named the 'Bistriy Reactor' (BR-1) or 'Fast Reactor'. In 1983, after several modifications of the BR-1, namely BR-2, BR-3, BR-4... and BR-10, the FBR BR-10 was able to produce $8 \mathrm{MWt}$. However, it was used mostly for research purposes. The FBR for mass electricity production was invented in 1959. Named the 'Bistriy Neutron-350' (BN-350) or 'Fast Neutron,' it was able to produce 120 MWt. In 1972, BN-350 which was constructed in the former Soviet republic of Kazakhstan was connected to the Kazakhstan grid in order to desalinate Caspian Sea water and produce electricity. Kazakhstan reactor BN350 was decommissioned in the beginning of the 1990s (Pomper 2009). Mass production of electricity from NPPs was started in 1970s when the basis of Russian nuclear energy technology was designed. The Soviet Union nuclear energy industry grew very fast and in 1981, the share of nuclear power in electricity generation was already 6.5 per cent (Semenov 1982). In 1980s, Soviet Union had 25 nuclear reactors in operation (Pomper 2009).

The atomic age inventions by the Soviet Union were not limited to the first nuclear reactor (1954), the FBR (1955), and the nuclear vessel (1959); the first moon rover Lunokhod-1(1970) that works on radioactive decay process was also invented by the USSR.

\section{ACCIDENTS THOSE HAVE IMPACTED RUSSIA'S EXPERIENCE WITH NUCLEAR ENERGY}

The USSR nuclear energy development is associated not only with success and progress but also with nuclear accidents. An estimated 754 people were victims of nuclear accidents, of which 350 suffered from radiation syndromes. Since the beginning of Russian nuclear industry, the total number of fatalities due to radiation contamination was estimated to be 71 (Shandala 2011). Among the NPP accidents, the most pronounced one was the Chernobyl accident.

The Chernobyl nuclear accident had huge impact in the USSR history. Anaykin (2011) believes that the Chernobyl accident led to the USSR collapse and even to the withdrawal of the USSR's troops from Afghanistan. The USSR could not bear the financial burden of both the war in Afghanistan and expenses in the Chernobyl nuclear accident.

The Chernobyl NPP accident is one of the biggest nuclear accidents in the world, a status that was later shared with Fukushima NPP accident (Leelossy et al. 2011). According to Saenko et al. (2011) major international organisations like the International Atomic Energy Agency (IAEA), the World Health Organisation (WHO), the United Nations International Children's Emergency Fund (UNICEF), and the International Agency for Research on Cancer (IARC) had carefully researched the consequences of the Chernobyl NPP accident. Many independent researchers had written articles and textbooks on the Chernobyl nuclear accident. However, even after 25 years, the research is not complete.

On 26 April 1986, the fourth reactor of the Chernobyl NPP exploded due to an operator's mistake (Balonov 2007). The highest level of radiation was registered in Belarus, Ukraine and Russia (Balonov 2007).In the same year, the Soviet Union authority sent a report to the IAEA regarding the resulting release of radiation. According to the report, 25 per cent of radiation had been released to the atmosphere instantly at the moment of explosion and the rest during the next 10 days (Ribakovskiy 1992).

Yablokov et al. (2010) indicated that the Russian scientists heavily criticised the report. Russian antinuclear activist, Prof. Yablokov, and many of his colleagues in Russia and abroad are sure that the methods and standards of radiation measurements may not provide realistic data. Moreover, on the basis of Prof. Yablokov's research, his European colleague, Prof. Busby, petitioned to the European Union Parliament to reconsider the Basic Safety Standards Directive of radiation producing practices, as standard does not reflect reality (EU Parliament Nuclear Justice 2012).Russian anti-nuclear activist, Prof. Yablokov, and many of his colleagues in Russia and abroad are sure that the methods and standards of radiation measurements may not provide realistic data. Moreover, on the basis of Prof. Yablokov's research, his European colleague, Prof. Busby, petitioned to 
the European Union Parliament to reconsider the Basic Safety Standards Directive of radiation producing practices, as standard does not reflect reality (EU Parliament Nuclear Justice 2012).

It is well known that one of the main health consequences of the Chernobyl nuclear accident is an increase of thyroid cancer as well as other diseases (Saenko et al. 2011). Prof. Yablokov and his colleague proposed a simple equation to measure the radiation impact based on a comparative analysis of cancer diseases reports before and after nuclear accident (Yablokov et al. 2010). According to the scientists' research, the difference between pre-Chernobyl and post-Chernobyl numbers of cancer, leukemia and psychological disorder reports is huge (Yablokov et al. 2010). Nevertheless, it is difficult to prove that radiation was the only reason for the increase of the diseases after a nuclear accident. Therefore, this method was based on formal logic and was not officially accepted. According to the official statements, the Chernobyl NPP accident caused 28 deaths due to radiation (Balonov 2007); the recent Japan's Fukushima NPP accident has not caused any death due to radiation (Ricotti 2013). Information on thousands of deaths due to the Chernobyl NPP accident is frequently based on Russian Prof. Yablokov's method of measuring radiation impact.

Franchino (2012) stated that the Chernobyl NPP accident raised not only national but also international concerns. A year after the accident, in November 1987, the Italian government called for a referendum regarding nuclear energy development. On the basis of the referendum's result, the government stopped promoting nuclear energy projects. In 1988, the Belgium government decided to stop the development of nuclear energy sector. Due to this decision, construction of the fifth reactor at the Doel NPP was postponed. In the same year, the German government stopped four new NPPs. An important lesson from the Chernobyl accident was that a nuclear energy accident is not only a concern of the hosting country; it is also an international problem.

The Chernobyl nuclear accident caused major changes in the IAEA approach toward nuclear energy safety. Moreover, the Chernobyl accident was the reason behind the formation of the World Association of Nuclear Operators (WANO), which along with the IAEA, created a platform for discussing nuclear safety issues at the international level (Perin 2005).

\subsection{Post-Chernobyl nuclear accident rumours}

Rahu (2003) did a research on the credibility of information after the Chernobyl NPP accident. He found that thelackof official information bred rumours and fears, which caused anxiety and consequently health problems. For example, after the Chernobyl accident, many Russian people believed that 15,000 Chernobyl accident victims were secretly buried in mass graves in the Ukrainian capital; or that the Chernobyl accident was an international experiment on the influence of radiation on people's health.

From the very beginning and till now, there were many rumours of animals and even human mutants living in prohibited zones around the Chernobyl NPP. Even a field research could not dispel these rumours, and they appear in the press from time to time. Aksyonenko (2012) informed that life is blossoming in the prohibited zone. After people forsook this land, nature fast replenished itself, population of live organisms started growing and even the variety of animals increased. Boars, wolves, deer, and other animals live in the Chernobyl NPP prohibited zone. Moreover, people who did not wish to leave their native places also live there.

The other popular rumour was linked to the USSR government. Some people believed that government officials evacuated their children from Kiev but children from other families were left in the contaminated city (Vorogcko 2011). As opposed to this rumour another one blamed the leader of the Soviet Ukraine V. V. Shcherbitsky for having put under risk not only the Ukrainian people and himself, but his own grandchildren, when he took them on the streets of Kiev to celebrate May Day with the public (Aksyonenko 2012). Some scientists believed that the Soviet Union government took all possible steps to minimize the negative consequences of the accident. For example, Prof. Busby argued that evacuation of the people in Japan was much slower than it was in Soviet Union (EU Parliament Nuclear Justice 2012). Nevertheless, people continue to blame the Soviet Union government. For people in Russia and other members of the USSR the Chernobyl NPP accident became a sign of the end of the USSR, and even was associated with the apocalypse.

The Chernobyl accident is also associated with the Biblical Apocalypse. In Bible it is written that a great star named Wormwood will fall from the heaven and will poison a third of the rivers and springs Wormwood is the Greek name of the plant that has bitter taste and was associated with poison. The star of apocalypse in Bible has name of this plant. Coincidently, the name of this grass in the Ukrainian language is Chernobyl the same name as the unfortunate NPP. Hence, some people associate the Chernobyl nuclear accident with apocalypse (Aksyonenko 2012). Theologians disagree with this association because this part of the Bible describes events that will happen after the second coming of Jesus Christ, and escalation of the Church to the heaven and only after that will be the end of the world (Jove 2006). Nonetheless, this idea is reflected in religious minds as in the mind of some politicians. It is more pronounced in the Ukraine nationalism discourse and officially supported by the Ukraine government. For example, the image of the star of apocalypse is included to the design of heraldic symbols of the Chernobyl NPP liquidators' city Slavutych (Image 1), which is 
situated in northern Ukraine (Slavutich Government 2012). Also, the memorial complex in Chernobyl city is named 'Wormwood/ChernobylStar' (Paskevich 2011).

\section{Image 1: Slavutich Town's Coat of Army}

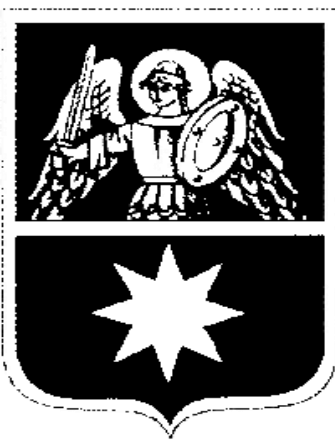

Source: Slavutich Government (2012)

It was not correct to associate the Chernobyl NPP accident with the end of the world but it could be correct to associate it with the last years of the USSR. On the basis of analysis of post-USSR discourse,Aksyonenko (2012) concluded that the environmental concerns and anti-nuclear activities facilitated the USSR collapse

\subsection{The Anti-Nuclear Movement in the USSR/Russia}

Chernobyl accident led to stagnation in nuclear energy sector and raised strong anti-nuclear movements (Pomper 2009). While nuclear energy was previously associated with progress, it became associated with harm in the post-Chernobyl period. The day on which the accident took place (26 April 1986) is considered the birthday of the anti-nuclear movement in the Soviet Union (Dawson 1996). Many anti-nuclear activities took place in the period spanning from the late 1980s till the collapse of the Soviet Union (Dawson 1996). After the Chernobyl accident, many anti-nuclear organisations emerged in the USSR.

According to Nikulina (2011), from 1988 to 1992, anti-nuclear activists prevented the construction of the following reactors:

- Reactor number 1 of the Kostroma NPP

- Reactors number 3 and 4 of the Kaliningrad NPP

- Reactor number 4 of the Beloyarsk NPP

- Reactors number 1 and 2 of the Rostov NPP

- Reactor number 5 of the Kursk NPP.

Moreover, 1990s was a period of referendums on the future of nuclear energy in Russia. For example:

- In the Khabarovsk region, 90 per cent of residents voted against the construction of Primorsky NPP.

- In Medvezhegorsk, 96 per cent of the citizens voted down the construction of Karelia NPP.

- In Voronezh, 90 per cent of people preferred construction of a thermal electric plant to a nuclear plant (Yefimova and Alimov 2008).

- In Chelyabinsk, 76 per cent of residents voted against nuclear energy and decided to close reactor number 1 of the South Ural NPP.

Victory was not always on the side of anti-nuclear activists. For example, the decision to stop construction of reactor number 4 of the Balakov NPP was the result of mass protest. Nevertheless, construction was not stopped. In 1992, the reactor was commissioned and connected to the grid (Nikulina 2011). Although local authorities announced that NPP had been stopped, the central government resumed the negotiation and continued the work on the NPP. When people came to know, the plant was already working.

The 2000s period was characterized by debates between public and nuclear energy establishment. For example, at the end of 2008, the cultural capital of Russia, St. Petersburg, witnessed a protest by 'nuclear monsters' against the construction of reactor number 2 in the Leningrad NPP. In this protest, Madame Zernova, a member of Russian political party Yabloko, raised public hopes of organizing a committee consisting of representatives fromthe state nuclear energy corporation Rosatom and the local community of SosnovyBor and coastal area of the Bay of Finland. This committee would discuss issues such as the following:

- Giving the local community a 50 per cent discount on the cost of electricity,

- Reducing the environmental impact of constructing the new NPP, and

- Fixing the time of decommissioning old NPPs in this region (Zernova 2008). 
Generally, anti-nuclear protests during the 2000s had few participants. In 2008, Nizhny Novgorod, a city famous for its anti-nuclear movement, hosted an anti-nuclear protest's programme consisting of anti-nuclear films, performances and music show. Only few activists participated.In the same year, other performances against nuclear energy took place in Nizhny Novgorod. The activists wore the costumes of death. During the activity, only 300 signatures of Novgorod's citizens against the construction of new nuclear plants in Russia were collected. At the end of the anti-nuclear show, the head of RosatomKiriyenko was bestowed with a rank of 'Nuclear Death of Russia' (Anisimova 2008).

In 2009, about 5,000 participants took part in one of the largest anti-nuclear protests in Murom city (Nikulina 2011). The only other similar protest that drew so many people was the gathering against nuclear plants construction in 1988 also in Nizhny Novgorod city, where 70 per cent of the city population protested. However, mass protests that were common in Russia under Soviet Union umbrella are rare in contemporarily Russia.

\subsection{The Fukushima nuclear accident}

The development of nuclear energy sector is highly dependent on public support. The history of Russian nuclear energy sector showed that people's negative perception may not only stop nuclear energy development but even detonate changes in the political system of the country. Aksyonenko 2012 argued that Chernobyl NPP accident was one of the reasons of the Soviet Union collapse.Therefore, how nuclear energy issues was reflected in national discourse after one of the biggest nuclear energy accidents at Japanese Fukushima NPP is an important question from both economic and political perspectives.

In 2011, the Fukushima nuclear plant accident put the nuclear energy programme in many countries under question (Cooke 2011). However, the accident did not change Russian government's plan of nuclear energy development. Moreover, Russian nuclear energy establishments were expected to find avenues in matters of the global cooperation in the post-Fukushima era. The energy establishments were expected to find opportunities in matters of the readjustment of nuclear energy technology market (Joskow and Parsons (2012). Although nuclear energy establishments promote nuclear energy development as a national interest, alternative point of view on nuclear energy issue became more and more pronounced after the Fukushima accident and even caused anti-nuclear protests in Russia. After the Fukushima accident, nuclear energy issues became dominant themes of the Russian energy policy agenda. The accident has brought in the recognition of the increasing importance of nuclear energy discourse. The Director General of Rosatom, Sergey Kiriyenko, pointed out that the main issue of nuclear power today is not technological, but psychological (Jukov 2012). Moreover, in interview to Russian Information Agency (2012) the first Deputy Director General of Rosatom, Lokshin,pointed out that nuclear power in Russia will die without public support. The Governmentpublic network is considered an important issue in contemporary Russian nuclear energy discourse.

Soon after the Fukushima NPP accident, the Russian government initiated testing of the current state of all nuclear plants and facilities and increased control over nuclear waste (Puhlih 2011). Russia's attempt to improve the image of nuclear energy is reflected in polls that have been conducted in Russia. For example, in the month of Fukushima NPP accident, the analytical centre Levada interviewed 1,600 Russians in 45 regions of the country. The results of the polls were the following:

- 98 per cent of Russian knew about the tragedy in Japan and felt deep compassion toward the Japanese tragedy.

- 52 per cent of Russians were in favour of nuclear power. Of these, 22 per cent were in favour of active development and 30 per cent in favour of maintaining the current level of nuclear power capacity (WNA 2014).

In 2012, the Levada Centre poll showed growth of support for nuclear energy. If in 2011, only 52 per cent of Russian people supported nuclear energy, in 2012 it was already 66 per cent. From this 66 per cent: 29 per cent were in favour of active development and 37 in favour of maintaining the current level of nuclear power capacity (WNA 2014).

One of the main Russian interests is to develop nuclear energy technologies for export. Even after Fukushima NPP accident, the Russia Federation did not change its energy strategy and Rosatomstillhas ambitions to develop nuclear energy in and outside Russia (Joskow and Parsons 2012).

\section{ECONOMIC DETERMINANT OF THE STATUS NUCLEAR ENERGY HAS IN RUSSIA}

The Soviet Union economy was based on industrial and territorial specialization where different plants in the huge territory of the country were involved in different steps of the manufacturing process; a planned economy synchronised the work of the various branches of the Soviet industry (Klochkova 2012). When Russia defaulted on its loans in 1998, the extensive cooperative networks and the planned economy were broken with 
the Soviet Union collapse which caused the collapse of entire economy. The rouble inflation came close to 100 per cent (Moran and Williams 2013).

In the post-Soviet Union period, Russian energy sector was privatized. During Yeltsin's presidency in 1990s, weak political system and rapid privatization led to accumulation of the natural recourses' profits in the hands of a small group of people (oligarchs) who were acting for their own interest rather than for the interests of the country (Chernykh 2008).

With the collapse of the Soviet Union in 1991, the USSR industry collapsed. The expected post-cold war Russia-USA partnership was not achieved. Furthermore, the Clinton administration, in the early 1990s, treated Russia as a defeated nation (Cohen 2011). Russia, which was the representative inheritor of the Soviet Union, became later a recipient of western aid (Gray 2011).

The rise of Russia and its nuclear energy sector is linked to Russian President Vladimir Putin. Before Putin comes to power, Russia had a big external debt that restricted the country from taking political decisions. Putin managed to get the oil and gas energy sector back under governmental control (Matteo 2012). Nowadays Russian energy sector is controlled by the government and highly interconnected with internal and external policy of the Russian Federation (Chernykh 2011). Putin nationalized the energy sector and was heavily criticized by western countries, which saw this step as going against democratic principles. Some political observers called Putin's policy anti-democratic and neo-imperialistic. However, Putin's reforms helped the economy and consequently Russia was able to pay off its external debt (Cohen 2011). Since the debt was a reason for the political dependency of the country's policy, paying off external debt and the resultant political independence allowed the Russian economy to grow. History repeated itself, as it was not the first time when national resources were nationalised and external debt was paid off.

During the first and second terms of Vladimir Putin's presidency, from 2000 to 2008, Russia's economy developed very fast (Hanson 2011). Russia became the seventh largest economy in the world in Purchasing Power Parity (PPP) having US\$2,076 trillion of purchasing power. From 2000 to 2011, Russian oil market grew by 56 per cent (Patterson 2008). The third President Dmitry Medvedev continued reforms that were launched by Putin. During the presidency of Dmitry Medvedev, Russia was number one in oil production in the world in 2009, and it produced a record of 511.4 million tons of oil in 2011 (Ickes 2013). In 2012, Russia covered 22 per cent of the world's gas demand. In other words, Russia became one of the largest producers of hydrocarbons in the world. After four years as Prime Minister, in 2012 Vladimir Putin was elected for his third term as President of Russian Federation and continued the development of the energy sector (Radyuhin 2012). However, Russia has not only positive but also negative sides from its fast oil and gas energy sector development. Russian economy became dependent on oil and gas export and its price on the world market. Energy sector stability has direct effect on a Russian federal budget. Nearly half of the Russian budget directly depends on oil and gas market price; Russian energy sector covers more than a quarter of Russia's gross domestic product (Matteo 2012). The Russian default in 1998 is one of the examples of the strong dependence of Russian economy onoil and gas prices. The default was caused by a dramatic drop of oil price that was lower than US\$13 per barrel. In the year of 2012, oil price was more than US\$100 per barrel (Matteo 2012). Russia needed an alternative to oil and gas export and one such product was nuclear energy technology and electricity generated by nuclear energy. Nuclear energy technology and electricity export is 'bread with butter' for Russia in case of low price for oil and gas. Therefore, attempting to balance Russian oil and gas export by the export of nuclear energy technologies is another aspect of nuclear energy discourse. The export of nuclear energy technology is promoted as an alternative to oil and gas exports (Malinetski 2011). And this scenario looks realistic as Russia holds the third position in the world market of civilian nuclear power technologies (Daly 2011).

\subsection{Russian nuclear energy renaissance}

From the Chernobyl NPP accident to Putin's de-privatization, Russia commissioned only one nuclear power station (WNA 2015). Russian nuclear energy renovation started in 2000s. After a long period of stagnation, Rostov-1, also known as Volgodonsk-1, was the first NPP that was commissioned in 2001. In the period from 2001 to 2006, Russian nuclear fuel export rose from US $\$ 2.5$ billion to US $\$ 3.5$ billion (WNA 2015).

In 2007, the Additional Protocol of NPT was ratified (WNA 2015). Other notable event that happened in 2007 was the establishment of the non-profit state nuclear energy corporation Rosatom, which holds all nuclear industry on behalf of the state (Shevchenko, Babikova and Khanina 2013). Rosatom deploys all necessary resources to create a fundamental base for nuclear energy development (Freeman 2007). For example, one of the leading universities in nuclear science, the Moscow Engineering and Physics Institute (MEPhI), is partly sponsored by Rosatom (WNA 2015).

In 1990s, Russia already had bilateral agreements with India, China, and Iran on nuclear energy technologies export. The number of Russian reactors in the world is increasing (Freeman 2007). Russia holds the third position in the world market of civilian nuclear power technologies after the USA and France (Daly 2011). 
Russian Pressurized Light Water-Moderated and Cooled reactors VVER-1000 have been built in the following countries:

- Bulgaria (Belene NPP)

- China (Yangjiang NPP)

- India (Kudankulam NPP)

- Iran (Bushehr NPP)

- Taiwan (Sanmen NPP)

- Ukraine (Kalinin 1-3 NPP, Temelin 1-2 NPP)

Russia is also planning to have contracts regarding NPPs construction in Bulgaria, Hungary, Argentina, and Vietnam (WNA 2015).

Russia offers highly competitive nuclear energy technologies among them VVER-1200 and Modernized International Reactor-1200 (MIR-1200). The VVER-1200 reactors with 1170 MWt net output have been built in Russia, Taiwan, and China, while MIR-1200 reactors have been introduced to Turkey and Finland (WNA 2015).

Russia financially supports those countries that are interested in nuclear energy development. Russia invested more than US\$7 billion in the economy of Belarus in 2012. Moreover, Russia gave to Belarus, US\$10 billion credit for 25 years to construct nuclear energy plants (Semak 2012).

Russia is offering to its clients:

- construction of NPPs

- fuels for NPPs

- operating of NPPs

- decommissioning of NPPs

Russia is also offering nuclear technologies in the medical field and space programmes. The Russian government assigned 500 million rubles for development of nuclear technologies for space projects (WNA 2015). Foreign orders on nuclear reactors construction had increased by 60 per cent to 66.5 billion by 2012, and by 25 per cent to over US $\$ 100$ billion by the end of 2014, up from US $\$ 2$ billion in 2000 (Mahroum 2016). It seems that nuclear energy will continue to play an important role in Russian energy sector as in the world energy market. Both technical and economic issues determine where Russia intends to go with nuclear industry.

\section{CONCLUSION}

Nuclear energy was among the tools that have been used to rebuild powerful USSR after the II World War. While development of nuclear energy played positive role in the Soviet Union'sprosperity, the Chernobyl NPP accident played negative role and caused stagnation in thenuclear energy sector. Currently nuclear energy is one of the hopes to build strong economy in Russia that will make it more independent from oil and gas price instability. The study shows that despite the fact that the country is rich of hydrocarbon recourse, historical and economic factors determined high status of nuclear energy in Russia.

\section{ACKNOWLEDGEMENTS}

I would like to begin by sincerely thanking Dr. Devika Sharma as this research would not have been possible without her constant guidance. Special thanks to Mrs. PolinaSharonova and Mr. Mikhail Sharonov for their constant, encouragement and inspiration. I am sincerely thankful to Indian Council for Cultural Relations for the financial support. I am particularly grateful to Mr. Munish Singh for his support and kind conduct.

\section{REFERENCES}

[1] Aksyonenko, S. (2012, May 24). Regarding Chernobyl mythology.Samizdatjournal.Retrieved from http://samlib.ru/a/aksenenko_s_i/cherb.shtml.

[2] Anaykin, A. (2011, Jul 11). Chernobyl and disorder of the USSR.Proza.Retrieved from http://www.proza.ru/2011/06/11/937.

[3] Andrews, J. T. (2013). An Evolving Scientific Public Sphere: State Science Enlightenment, Communicative Discourse, and Public Culture from Imperial Russia to Khrushchev's Soviet Times. Science in Context, 26(03), 509-526.

[4] Anisimova, P. (2008, April 28). Nizhny Novgorod anti-nuclear activists awarded to Sergey Kiriyenko a rank-Nuclear death of Russia. Arguments and Facts.Retrieved from http://www.aifnn.ru/society/details/509142.

[5] Balonov, M. I. (2007). The Chernobyl forum: major findings and recommendations. Journal of environmental radioactivity, 96(1), 6-12. 
[6] Chernykh, L. (2008). Ultimate ownership and control in Russia. Journal of Financial Economics, 88(1), 169-192.

[7] Chernykh, L. (2011). Profit or politics?Understanding renationalization in Russia.Journal of Corporate Finance, 17(5), 1237-1253.

[8] Cohen, S. (2011). Obama's Russia 'Reset': Another lost opportunity? Nation, 292 (25).

[9] Cooke, S. (2011). After Fukushima, does nuclear power have a future? New York Times, 10, 451-54.

[10] Daly, J. (2011, July 06). Despite Fukushima, Russia's nuclear industry is open for business. Oil and Energy News.Retrieved from http://oilprice.com/Alternative-Energy/Nuclear-Power/Despite-FukushimaRussias-Nuclear-Industry-is-Open-for-Business.html.

[11] Dawson, J. I. (1995). Anti-nuclear activists in the USSR and its successor states: A surrogate for nationalism? Environmental Politics, 4(3), 441-466.

[12] EU Parliament Nuclear Justice. (2012, May 06). [Video] Chris Busby's the EU parliament petition for Euratom justification. ICNJ Existential NJ Research.Retrieved fromhttp://nuclearjustice.org/?p=50.

[13] Franchino, F. (2012, May 4).The social bases to nuclear energy policies in Europe: priors, proximity, belief updating and attitudes to risk.Paper presented at the 2nd Annual General Conference of the European Political Science Association, 21-23 June 2012 Panel 2503: Public Opinion and Risk. Retrieved fromhttps://air.unimi.it/retrieve/handle/2434/175441/184518/Franchino_Attitudes\%0to\%20nuclear\%20ri sk.pdf.

[14] Freeman, M. (2007, December 14). Russia's nuclear energy plan for the next fifty years.Exclusive Inelegancy Review Report.Retrievedfrom http://www.larouchepub.com/eiw/public/2007/eirv34n4920071214/42-45_749.pdf.

[15] Gray, P. A. (2011). Looking 'The Gift' in the mouth: Russia as donor.AnthropologyToday, 27(2), 5-8.

[16] Hanson, P. (2011). Russia: Crisis, Exit and... Reform? Journal of Communist Studies and Transition Politics, 27(3-4), 456-475.

[17] Ickes, B. (2013). Russia: Energy security issues. Apaper presented at the Economics of energy and energy security conference, The Pennsylvania State University.Spring 2013.

[18] Joskow, P. L. and Parsons, J. E. (2012).The future of nuclear power after Fukushima.Economics of Energy and Environmental Policy. 1(2), 99-113.

[19] Jove (Gumerov) Hieromonk (2006, March 13). Questions to a priest.Pravoslavie.Retrieved from http://www.pravoslavie.ru/answers/.

[20] Jukov, A. (2012, Jun 21). The main issue of nuclear power today is not technological, but psychological. RBK daily.Retrieved from http://www.proatom.ru/modules.php?name=News\&file=article\&sid=3854.

[21] Klochkova, M. (2012).Prospects for Russian-Ukraine nuclear cooperation.Security Index. 2 (99), 25-38.

[22] Lapayeva, G., and Lapayev, F. (2004).Main steps of Russian energy sector's growth.Messenger of the Orenburg state university.8, 4-12.

[23] Leelossy, Á.,Mészáros, R., and Lagzi, I. (2011). Short and long term dispersion patterns of radionuclides in the atmosphere around the Fukushima Nuclear Power Plant. Journal of environmental radioactivity, 102(12), 1117-1121.

[24] Levchuk, P.P. (2011). History: Ilyich’s Bulbs. Amur scientific messenger. 2, 110-117.

[25] Maevskiy, I. (1957). Russian participation in the First World War.History questions. 1, 69-77.

[26] Mahroum, S., and Al-Saleh, Y. (Eds.).(2016). Economic Diversification Policies in Natural Resource Rich Economies.Routledge.

[27] Malinetski, G. (2011). Modernization of Russia and the design of the future.Information war.4 (20).3137.

[28] Matteo,V. (2012, November). Russian Oil and Gas Sector: Political and Economic Prospects. ISPIAnalysis.№147.

[29] Mitrova, T. (2014). Review of the 'Global and Russian energy outlook up to 2040'. Energy Strategy Reviews, 2(3), 323-325.

[30] Moran, M., and Williams, H. W. (2013).Keeping up appearances: National narratives and nuclear policy in France and Russia.Defence Studies, 13(2), 192-215.

[31] Nikulina, A. (2011). The Russian Anti-Nuclear Movement.Russian analytical digest.№101.

[32] Paskevich, S. (2011, May).Chernobyl today, memorial complex 'Wormwood Star'.Chernobyl.in.ua.Retrieved from http://chornobyl.in.ua/chernobyl-zvezda-polyn.html.

[33] Patterson, A. (2008, September 10). Overview of the world's ten largest economies.Ezinearticles.com.Retrieved from http://ezinearticles.com/?Overview-of-the-Worlds-TenLargest-Economies\&id=1484083.

[34] Perin, C. (2005). Shouldering risks: the culture of control in the nuclear power industry. Princeton, NJ: Princeton University Press. 
[35] Pomper, M. (2009).Nuclear Energy Futures Papers.The Russian Nuclear Industry Status and Prospects.The Centre for International Governance Innovation. Paper No. 3.

[36] Puhlih, L. (2011, March 16). Explosions at Japanese nuclear power plants can raise the price of gas and electricity. Arguments and Facts.Retrievedfrom http://www.aif.ru/money/market/24089.

[37] Radyuhin, V. (2012, May 8). Putin returns as Russian President. The Hindu.Retrieved from http://www.thehindu.com/todays-paper/tp-international/putin-returns-as-russianpresident/article3395482.ece.

[38] Rahu, M. (2003). Health effects of the Chernobyl accident: fears, rumours and the truth. European Journal of Cancer, 39(3), 295-299.

[39] Ribakovskiy, L. (1992). Demographic consequences of the Chernobyl accident.Social demography. 9 , 40-50.

[40] Ricotti, M. E. (2013). Nuclear energy: basics, present, future. EPJ web of conferences.EDP Sciences.54,01005.

[41] RussHydro.ru. (2011).Russian http://www.rushydro.ru/industry/russianhydropower/.

[42] Russian Information Agency. (2012, 5 September). The nuclear power in the Russian Federation needs public support. RIA News. Retrieved from http://www.ria.ru/atomtec_news/20120905/743554229.html.

[43] Saenko, V., Ivanov, V., Tsyb, A., Bogdanova, T., Tronko, M., Demidchik, Y., and Yamashita, S. (2011). Chernobyl NPP accident and its consequences.Clinical Oncology, 23(4), 234-243.

[44] Semak, H. (2012) Russian investments in the economy of the Republic of Belarus.Baltic Rim Economies Expert article, 1, 121.

[45] Semenov. A. (1982).Nuclear power.Nuclear power in the Soviet Union.IAEA Bulletin, 25(2).

[46] Shandala, N. (2011, October 17). Protective Measure and Criteria Development: the experience relating to the accident at the Chernobyl NPP. Paper presented at the first international symposium on decontamination, Fukushima, Japan.

[47] Shevchenko, I. K., Babikova, A. V., and Khanina, A. V. (2013).Conditions and stages of formation and development of the state corporations in the Russian economy.Modern scientific research and their practical application, 11313.

[48] Singh, M. K. (2013). Indian's nuclear policy. Sumit Enterprises, New Delhi.

[49] SlavutichGovernment.(2012). Slavutich' flag and coat of army [images]. E-slavutich.gov.ua. Retrieved from http://www.e-slavutich.gov.ua/SitePages/home.aspx.

[50] Slovic, P. and Peters, E. (2006). Risk perception and affect. Current directions in psychological science, 15(6), 322-325.

[51] Solanko, L. (2013). Successes in Arctic oil and gas development remain elusive. Perspectives on Russia's energy sector. $3,12-15$

[52] Vorogcko, T. (2011, April 27). Chernobyl became the prerequisite of the USSR collapse [Radio broadcast episode]: Voice of America. Retrieved from http://inotv.rt.com/2011-04-27/CHernobil-stalpredposilkoj-k-raspadu.

[53] WNA. (2014, March). Russia's nuclear fuel cycle.Public opinion [Data set].World Nuclear Association [Producer].Retrieved from http://www.world-nuclear.org/info/Country-Profiles/Countries-O-S/Russia-Nuclear-Fuel-Cycle/\#Public Opinion.

[54] WNA. (2015, January 19). Nuclear power in Russia.World Nuclear Association.Retrieved from http://www.world-nuclear.org/info/Country-Profiles/Countries-O-S/Russia--Nuclear-Power/.

[55] Yablokov, A. V., Nesterenko, V. B., Nesterenko, A. V., and Sherman-Nevinger, J. D. (Eds.). (2010). Chernobyl: Consequences of the Catastrophe for People and the Environment. Moscow, Russia.

[56] Yefimova, Ye.andAlimov, R. (2008, August 21). Fate of southern Urals nuclear power plant to be decided in Russia Supreme Court.Bellona.Retrieved from http://bellona.org/news/nuclear-issues/nuclearrussia/2008-08-fate-of-southern-urals-nuclear-power-plant-to-be-decided-in-russia-supreme-court.

[57] Yerofeev, N. (2003). Population standard of living in Russia at the end of XIX - the beginning of the XX century.History, 1, 55 - 70 .

[58] Zernova, L. (2008). A local's perspective on peaceful nuclear energy: a heavy hand.Paper presented at the second Russian national dialogue on energy, society and security 21-22 April: Green Cross Russia, Green Cross Switzerland, Global Green USA. Saint Petersburg, Russia.

[59] Zhmurikov, E. I., Bolkhovityanov, D. Y., Blinov, M. F., Ishchenko, A. V., Kot, N. K., Titov, A. T., ... and Luigi, T. (2010). On the problem of reactor graphite lifetime.Journal of Surface Investigation, 4(3), 442-451. 